\title{
Attitudes of Jordanians People toward Employment of Persons with Disabilities*
}

\author{
Rodaina Khader Ibrahim Al Tarawneh \\ Faculty of Educational Sciences, Mu'tah University, Karak, Jordan \\ Email: rodainatarawnah@yahoo.com
}

How to cite this paper: Al Tarawneh, R.K.I. (2016) Attitudes of Jordanians People toward Employment of Persons with Disabilities. Open Journal of Social Sciences, 4, 140-157. http://dx.doi.org/10.4236/iss.2016.49013

Received: August 17, 2016

Accepted: September 19, 2016

Published: September 22, 2016

Copyright $\odot 2016$ by author and Scientific Research Publishing Inc. This work is licensed under the Creative Commons Attribution International License (CC BY 4.0).

http://creativecommons.org/licenses/by/4.0/ (c) (i) Open Access

\begin{abstract}
This study aimed to know the attitudes of Jordanians people toward employment of persons with disabilities, and it aimed to investigate the effect of some variables on these attitudes. In order to achieve the aims of this study, a questionnaire of attitudes toward employment of persons with disabilities were used to collect data from 800 persons (344 males and 456 females). The results indicated that the percentage of Jordanians people who emphasized that the work was a right for people with disabilities was (88.5\%), and the percentage of Jordanians people who pointed out that people with disabilities unproductive was (69\%). Also it indicates that there are statistically significant differences between the Jordanians people in the attitudes toward employment of persons with disabilities due to (Age, Educational level and Existence of a disability in the individual's family). Also there are no statistically significant differences between Jordanians people in the attitudes due to (Gender and Economic level).
\end{abstract}

\section{Keywords}

Attitudes, Employment, Persons with Disabilities

\section{Introduction}

Jordan signed and ratified on the International Convention on the Rights of Persons with Disabilities in 2007 (Higher Council for affairs of person with Disabilities \{HCD\}, 2007) [1], and it has been for it a general obligation to ensure and promote the full realization of all human rights without any kind of discrimination based on their disability. Nationally, Jordan has developed laws which allow people with disabilities to have easy access to employment. However, the reflection of this in practice is quite different, for it lacks logic and a coherent pattern (Bitar, 2013) [2].

${ }^{*}$ Dedicated to Professor Khawla Yahya. 
Law on the Rights of Persons with Disabilities (Law number 31 for the year 2007) (obligates institutions of private and public nature who employ 25 - 50 employees, to hire at least one person with disabilities, and if the total number of workers exceeds 50, (4\%) of the work force should be from persons with disabilities (HCD, 2007 [3]). The existence of the law is the only way to ensure that people with disabilities work, and percentages in the law known as the quota system, a quota system that obliges employers to ensure that certain proportion of their employees are persons with disabilities, it is not based on the competition according to qualifications and skills, but a specific percentage in the law, it means that people with disabilities are treated separately and remain excluded from all other potential-employees (Bitar, 2013 [2]).

In all countries of the world, persons with disabilities suffer from unemployment at a higher rate compared to persons without disabilities. (Abdat, 2014 [4]; Balcazar, Kuchak, Dimpfl, Sariepella \& Alvarado, 2014 [5]; Henry, Petkauskos, Stanislawzyk \& Voget, 2014 [6]; Jang, Wang \& Lin, 2013 [7]; Nyombi \& Kibandama, 2014 [8]; Siperstein, Heyman \& Stokes, 2014 [9]; Stone, 1999 [10]; Benshoff, Barrera \& Heymaan, 2014 [11]; Volker, 2014 [12]; Coleman, Sykes \& Groom, 2013 [13]; Gustafsson, Peralta \& Danermark, 2013 [14]; Jang, Wang \& Lin, 2014 [15]; International Labour Organization, 2013 [16]; Komarnicki, 2014 [17]; Nord, luecking, Mank, Kiernan \& Wary, 2013 [18]; Nota, Rumrill, Fraser \& Johnson, 2013 [19]; US department of Lobor, 2013 [20]; Vornholt, Uitdewilligen \& Nijhuis, 2013 [21]; Sing, 2012 [22]; Volker, 2012 [23]; Berthoud, 2011 [24]; Crawford, 2011 [25]; Mansour, 2009 [26]; National Disability Authority, 2005 [27]; Thornton \& Lunt, 1995 [28]; Barnes, 1992 [29]). In Jordan, the employment rate among persons with disabilities is low (Abu Melhim, 2015 [30]; Abu Sain, 2015 [31]; Bitar, 2013 [2]; HDC, 2010 [32]), almost, 7.7\% of people with disabilities are employed (Azzeh, 2015 [33]). The female unemployment rate is higher than males (Abu Melhim, 2015 [30]). (12\%) from employed persons with disabilities in Jordan are women and (88\%) from them are males) (HCD, 2010 [32]). Usually in Jordan is the employment of persons with disabilities on the humanitarian cases because of disability, or according to a quota system or to the qualifications. Ababneh (2016 [34]) found in his study which conducted in Jordan on (198) employee with a disability in the public sector. That (55\%) of those employees employed on the humanitarian cases because of their disability. And (45\%) of them were employed according to their qualifications.

Studies show that many persons with disabilities want to work, (Henry, et al., 2014 [6]; Nord, et al., 2013 [18]; Thornton \& Lunt, 1995 [28]; Heron \& Murray, 2003 [35]). And they can do so (Thornton \& Lunt, 1995 [28]; Heron \& Murray, 2003 [35]; Lysaght, Ouellette-Kuntz \& Jung Lin, 2012 [36]). Because work is not only needed to earn a living, but also fulfills a number of basic human needs (Nota et al., 2013 [19]; Vornholt et al., 2013 [21]). they are many benefits of working and employment for people with disabilities, like: it can provide persons with disabilities with financial independence (Jang et al., 2013 [7]; Nord et al., 2013 [18]; Heron \& Murray, 2003 [35]; Paez \& Arendt, 2014 [37]; Arikawa, Goto \& Mineno, 2013 [38]). support meaningful participation for persons with disabilities in community and benefit from their potential (Jang et al., 2013 [7]), 
improve health and well-being (Jang et al., 2013 [7]; Vornholt et al., 2013 [21]; Heron \& Murray, 2003 [35]), increase confidence (Jang et al., 2013 [7]; Heron \& Murray, 2003 [35]), Work is one opportunity to reduce this isolation for persons with disabilities and expand social networks (Jang et al., 2013 [7]; Vornholt et al., 2013 [21]; Heron \& Murray, 2003 [35]; Paez \& Arendt, 2014 [37]), different skills development and increased life satisfaction and increase civic skills (Paez \& Arendt, 2014 [37]).

Some studies have indicated that there positive attitudes towards the employment of persons with disabilities (Gustafsson et al., 2013 [14]; Paez \& Arendt, 2014 [37]; Employment monitoring and evaluation branch, 2011 [39]; Siperstein, Romano, Mohler \& Parker, 2006 [40]; Florence, 2003 [41]; Hernandez, Keys \& Balcazar, 2000 [42]; Minskoff, Sautter, Hoffmann \& Hawks, 1987 [43]). Employment of persons with disabilities requires the assessing the occupational performance of the persons and the work environment and understanding the characteristics of the job by experiencing, first then, adjusting or improving the work environment to match the capabilities of the persons (Arikawa et al., 2013 [38]), the job matching process requires good quality information about job seekers with disabilities to determine experience, skills, interests, education and general capacity. The process also requires good quality information about jobs, including the specific tasks to be performed, the standards of performance required, the conditions under which the work is performed and the organizational setting in which the work takes place (Boman, Kjellberg, Danermar \& Boman, 2013 [44]; Heron, 2005 [45]).

Although employment is a right for persons with disabilities emphasized by the laws (HCD, 2007 [1]; Bitar, 2013 [2]), but that there is a gap between the law and its implementation (Bitar, 2013 [2]; Nyombi \& Kibandama, 2014 [8]; Stone, 1999 [10]; Nota et al., 2013 [19]; Vornholt, et al., 2013 [21]; National Disability Authority \{NDA\}, 2005 [27]; Wilgosh \& Skaret, 1987 [46]). This because of negative attitudes and misconceptions of some employers and people toward the idea of employment persons with disabilities (Abdat, 2014 [4]; Henry et al., 2014 [6]; Nota et al., 2013 [19]; US Department of Labor, 2013 [20]; Wilgosh \& Skaret, 1987 [46]; Woodely \& Metzgr, 2012 [47]; Kaye, Jans \& Jones, 2011 [48]; Robert \& Melina, 2005 [49]; Berry \& Meyer, 1995 [50]; Kilbury, John \& Stanford, 1992 [51]), and they don't have a clear policy regarding the employment of such type of workers (Mansour, 2009 [26]). many studies suggest that there are fears that the employment of persons with disabilities, such as the employers may be concerned that employees with disabilities have lower work productivity (Abdat, 2014 [4]; Hery et al., 2014 [6]; Mansour, 2009 [26]; Barnes, 1992 [29]; Hernandez, et al., 2000 [42]; Woodely \& Metzgr, 2012 [47]; Kaye, et al., 2011 [48]; McDonnall, 2014 [52]; Domzal, Houtenville \& Sharma, 2008 [53]; Fuqua, Rathbun \& Gade, 1984 [54]), the cost of accommodations (Henry et al., 2014 [6]; US Department of Labor, 2013 [20]; Hernandez et al., 2000 [42]), higher rates accident and work Injuries also higher compensations (Henry et al., 2014 [6]; Woodely \& Metzgr, 2012 [47] equa et al., 1984 [54]), lack of skills enough to do work and no hassle (Henry et al., 2014 [6]; Mansour, 2009 [26]; Barnes, 1992 [29]; Hernandez et al., 2000 [42]; Woodely \& Metzgr, 2012 [47]; Kaye et 
al., 2011 [48]; Domzal et al., 2008 [53]), higher rates absence and additional costs (Henry et al., 2014 [6]; Woodely \& Metzgr, 2012 [47]; Kaye et al., 2011 [48]; Domzal et al., 2008 [53]), persons with disabilities can't work heavy work (Barnes, 1992 [29]), were barriers to employment in their own workplaces (Woodely \& Metzgr, 2012 [47]), Working not be comfortable with persons with disabilities (Henry et al., 2014 [6]; Woodely \& Metzgr, 2012 [47]), greater supervision compared to persons without disabilities (Henry et al., 2014 [6]; Kaye et al., 2011 [48]; Domzal et al., 2008 [53]), lack of access to practical training work experience and education (Komarinicki, 2014 [17]; US Department of Labor, 2013 [20]), lack of soft skills (e.g., communication, language, ability to interact effectively with employers (Komarinicki, 2014 [17]; US Department of Labor, 2013 [20]), finally customers and clients would not be particularly comfortable dealing with disabled people (Woodely \& Metzgr, 2012 [47]).

Employees with disabilities are facing difficulties in their work (Heron \& Murray, 2003 [35]; Stephens, Collins \& Dodder, 2005 [55]) like, when they are found work, the majority find themselves in poorly paid (Jang et al., 2013 [7]; Nyombi \& Kibandama, 2014 [8]; Crawford, 2011 [25]; Thornton \& Lunt, 1995 [28]; Barnes, 1992 [29]; Heron \& Murray, 2003 [35]), low skills and education or poor work experience and no useful vocational qualification (Abdat, 2014 [4]; Stone,1999 [10]; Jang, et al., 2014 [15]; Barnes, 1992 [29]; Heron \& Murray, 2003 [35]; Paez \& Arendt, 2014 [37];), they get low status jobs which are unrewarding and undemanding \{underemployment\} (Jang et al., 2013 [7]; International labour organization, 2013 [16]; Crawford, 2011 [25]; Thornton \& Lunt, 1995 [28]; Barnes, 1992 [29]) or refused a job promotion (International labour organization, 2013 [16]; Crawford, 2011 [25]).

Also difficulty with transport (Coleman et al., 2013 [13]; Heron \& Murray, 2003 [35]), lack of social acceptance persons with disabilities by employers, colleagues or customers without disabilities is often be reasoned why employees with disabilities fail to stay in regular organization for sustained period (Vornholt et al., 2013 [21]), anxiety or lack confidence in workplace (Coleman et al., 2013 [13]), issues relating to access and support \{e.g. difficulty getting into buildings, difficulty using facilities and lack of special aids or equipment\} (Abdat, 2014 [4]; stone, 1999 [10]; Coleman et al., 2013 [13]; Jang et al., 2014 [15]; Komarnicki, 2014 [17]; Vornholt et al., 2013 [21]; Heron \& Murray, 2003 [35]), Lack of awareness of the importance employment for persons with disabilities (Henry et al., 2014 [6]; Heron \& Murray, 2003 [35]; Kulkarni \& Kote, 2013 [56]), lack of awareness in the laws which related with employment for persons with disabilities (Abu Melhim, 2015 [30]), lack of the employing offices for the employment of persons with disabilities (Henry et al., 2014 [6]; Kulkarni \& Kote, 2013 [56]), were given less responsibility than colleagues without disabilities, were denied a workplace accommodation, were denied other work-related benefits (Crawford, 2011 [25]), low self-esteem and overprotective families, lack of a supportive legal environment and lack of policy support and rapidly changing labour markets (Heron \& Murray, 2003 [35]) finally, negative attitudes of employers or colleagues and customers (Abdat, 2014 [4]; Henry et al., 2014 [6]; Stone, 1999 [10]; Coleman et al., 2013 [13]; Komarnicki, 2014 
[17]; Crawford, 2011 [25]; Thornton \& Lunt, 1995 [28]; Heron \& Murray, 2003 [35];

Paez \& Arendt, 2014 [37]; Domzal et al., 2008 [53]).

The attitude towards persons with disabilities is important in employment, attitudes affected by the number of variable, including:

1) Type and severity of disability can affect employers' employing decisions(Henry et al., 2014 [6]; Komarnicki, 2014 [17]; Nota et al., 2013 [19]; Vorntholt et al., 2013 [21]; Crawford, 2011 [25]; National disability authority, 2005 [27]; Paez \& Arendt, 2014 [37]; Siperstein et al., 2006 [40]; Hernandez et al., 2000 [42]; Minskoff et al., 1987 [43]; Woodely \& Metzgr, 2012 [47]; Fuqua et al., 1984 [54]; Stephens, et al., 2005 [55]; Unger, 2002 [57]; Gilbride, Stensured, Ehlers, Evans \& Peterson, 2000 [58]; Smith, 1981 [59]; Mithaug, 1979 [60]).

2) Gender, the attitudes toward employing men with disabilities are better compared to women with disabilities (Komarnicki, 2014 [17]; National disability authority, 2005 [27]; Heron \& Murray, 2003 [35]; Boman et al., 2013 [44]).

3) Many studies indicated that the employers with experience working with persons with disabilities have more favorable attitudes toward employees with disabilities (Henry et al., 2014 [6]; Gustafsson, et al., 2013 [14]; Nota et al., 2013 [19]; Vornholt et al., 2013 [21]; Wilgosh \& Skaret, 1987 [46]; Robert \& Melina, 2005 [49]; McDonnal, 2014 [52]; Unger, 2002 [57]; Hernandez, McDonald, Divilbiss, Horin, Velcoff \& Donoso, 2008 [61]). Some studies have indicated that there are no differences in attitudes towards the employment of persons with disabilities due to the variable to experience work with people with disabilities (Paez \&Arendt, 2014 [37]; Woodely \& Metzgr, 2012 [47]).

4) The number of employees in the workplace, there were positive attitudes towards the employment of persons with disabilities in large companies-in which a large number of employees-(Henry et al., 2014 [6]; Florence, 2003 [41]).

5) Age, the attitudes towards the employment of young people who have a disability are positive compared to older people who have a disability (Vorntholt et al., 2013 [21]).

6) Education for persons with disability (Vorntholt et al., 2013 [21]; Boman et al., 2013 [44]).

7) Type of work, if it was considered appropriate for persons with disabilities (Nota et al., 2013 [19]).

The most important things that help the employment of persons with disabilities are the positive attitudes towards them, because of positive attitudes lead to:

1) The existence of legislation and laws binding at the employment of persons with disabilities. This is an important variable in the employment of persons with disabilities (Benshoff, Barrera \& Heymann, 2014 [11]; Nord et al., 2013 [18]; Volker, 2012 [23]; Abu Melhim, 2015 [30]; Florence, 2003 [41]).

2) The education of persons with disabilities, and establishing special centers for vocational habilitation and training for people with disabilities. Because it helps them get a job (Abdat, 2014 [4]; Henry et al., 2014 [6]; Jang et al., 2013 [7]; Komarniciki, 2014 
[17]; Kulkarni \& Kote, 2013 [56]).

3) Establishing employing offices for the employment of persons with disabilities, because companies do not know how to reach people with disabilities (Jang et al., 2013

[7]). the employing offices have two major roles: the first, helping jobseekers find suitable employment. Second, helping enterprises find suitable staff (Henry et al., 2014 [6]; Volker, 2014 [12]; Heron \& Murray, 2003 [35]).

4) Establishing sheltered workshops for some persons with disabilities, who are can't work with persons without disabilities (Jang et al., 2014 [15]; Visier, 1998 [62]).

Briefly, due to the importance of attitudes towards the employment of persons with disabilities to get a job. This study was conducted to identify the attitudes of Jordanians people towards the employment of persons with disabilities. In order to reach recommendations that would improve opportunities get a work for persons with disabilities. Therefore, the questions of this study are:

First: What are the attitudes of Jordanians people towards employment of persons with disabilities?

Second: Are there any statistically significant differences between Jordanians people in the attitudes towards employment of persons with disabilities due to (gender, age, educational level, economic level and the existence of a disability in the individual's family)?

\section{Methods}

This descriptive study describes attitudes of Jordanians people toward employment of persons with disabilities. It is also a comparative study, to see the differences in the attitudes of Jordanians people depending on variables (gender, age, educational, level economic level and the existence of a disability in the individual's family).

\subsection{Study Participants}

The numbers of participants in this study were 800 persons from Jordan, Age (20-60 years). They were randomly selected from all the cities of Jordan (the North (200 persons), middle (400 persons) and South (200 persons). Table 1 shows the demographic characteristics of the participants in this study.

\subsection{Study Instrument}

The Attitudes toward employment of persons with disabilities questionnaire were used to measure attitudes of Jordanians people toward employment of persons with disabilities. And to investigate the effect of variables (gender, age, educational level, economic level and the existence of a disability in the individual's family) on these attitudes. The study Instrument was developed by researcher it finally consisted of 18 items (positive and negative), the content validity for the questionnaires was established, also computed reliability of the questionnaires by Cronbach alpha's formula, it was (0.834). The highest score on the questionnaire is 90 , the scores on the negative items (rejects employment of persons with disabilities were calculated as the following (strongly agree 
Table 1. Demographics of Participants $(n=800)$.

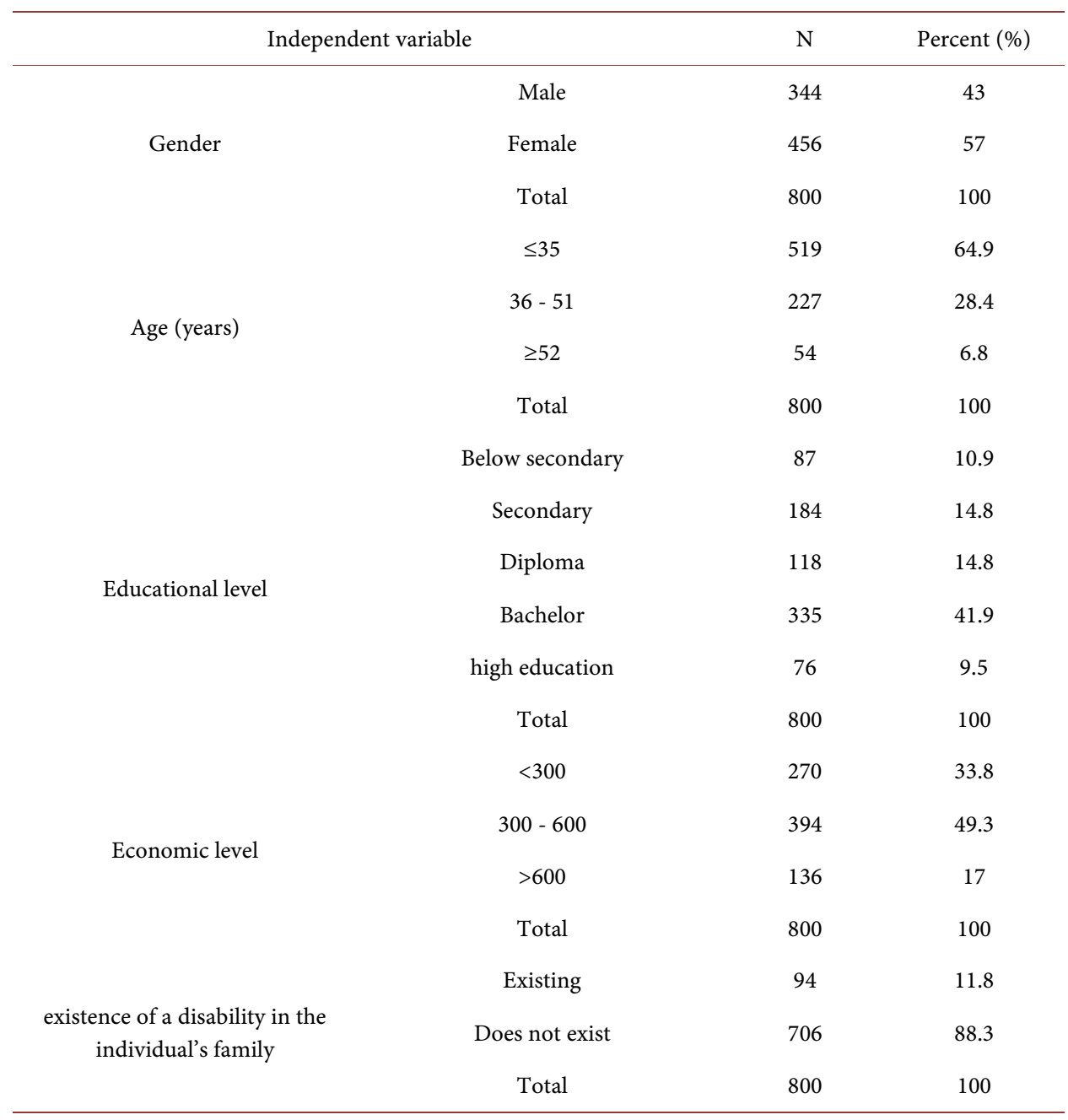

$=1$, agree $=2$, neutral $=3$, disagree $=4$, strongly disagree $=5$ ). And scores on the positive items (supports an employment of persons with disabilities) were calculated as the following (strongly agree $=5$, agree $=4$, neutral $=3$, disagree $=2$, strongly disagree $=1$ ) .

\subsection{Data Collection and Analysis}

Applied questionnaires on the Jordanians people age (20 - 60) from all the cities in Jordan. Special education students at Mu'tah University who live in different cities of Jordan helped a researcher in collecting the data. After collecting a number of questionnaires, the study sample was selected randomly.

For analysis data, to answer the first questions of the study "What are the attitudes of Jordanians people toward employment of persons with disabilities?" frequencies and percentages for the responses of study participants on each item were computed. To answer the second question "Are there any statistically significant differences between Jordanians people in the attitudes towards employment of persons with disabilities due to (gender, age, educational level, economic level and the existence of a disability in the 
individual's family)?"

5 way ANOVA test was used to know differences in attitudes toward employment of persons with disabilities.

\section{Results and Discussion}

To answer the first question "what are the attitudes of Jordanian people toward employment of persons with disabilities?" Frequencies and percentages for the responses of study participants on each item were computed. Table 2 shows that.

Table 2. Frequencies and percentages for the responses of study participants on each item.

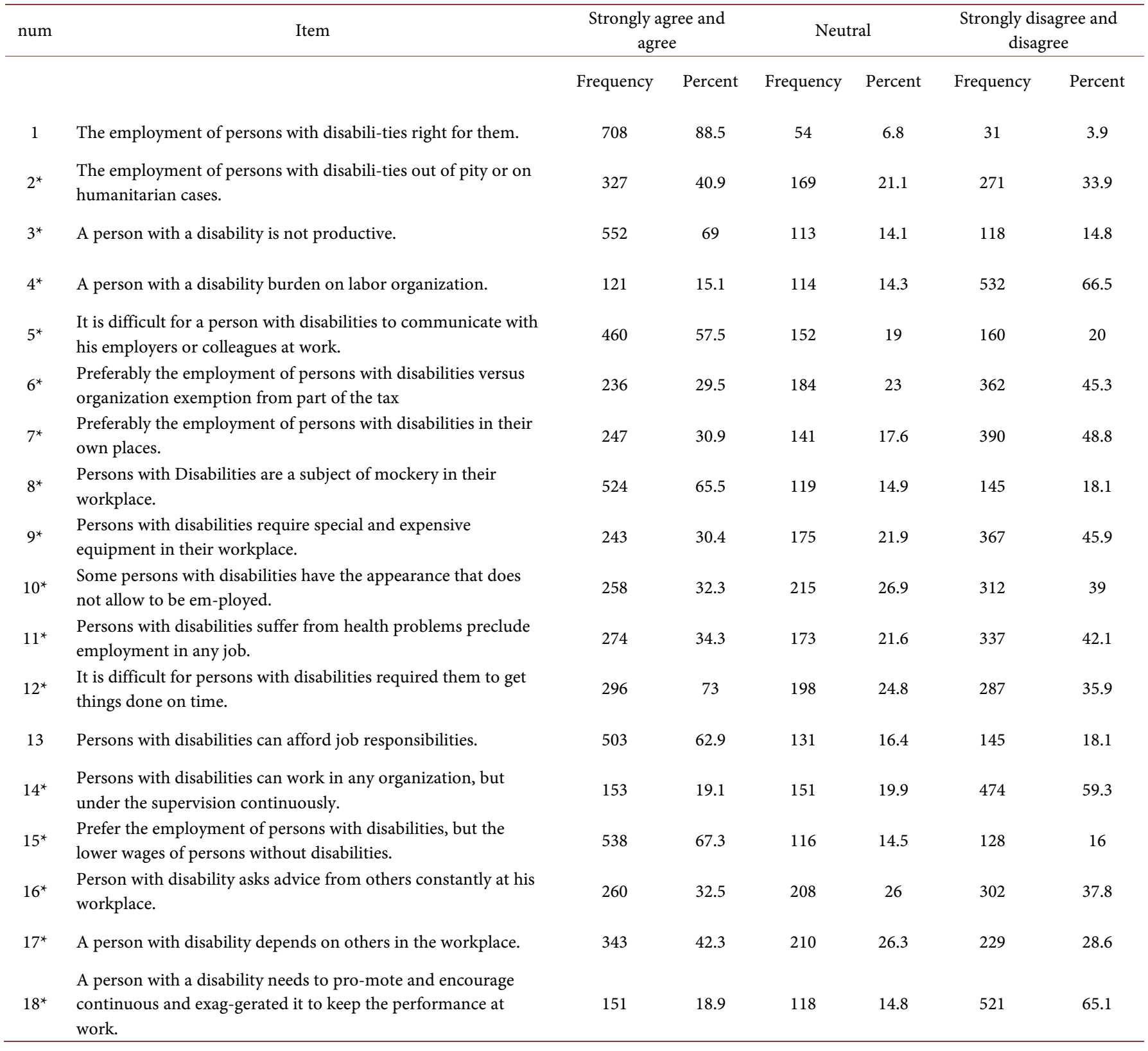

*negative item some people did not answer the paragraphs. 
Table 2 shows that the opinions about employment of persons with disabilities varying and different. According item (1) "The employment of persons with disabilities right for them". About $88.5 \%$ of respondents indicated that the right to employment for persons with disabilities. This result reflects the positive attitudes towards the employment of persons with disabilities, this result agrees with the results of studies (Gustafsson et al., 2013 [14]; Paez \& Arendt, 2014 [37]; Employment monitoring and evaluation branch, 2011 [39]; Siperstein et al., 2006 [40]; Florence, 2003 [41]; Hernandez et al., 2000 [42]; Minskoff et al., 1987 [43]). Item (3) "A person with a disability is not productive" is a very negative item; about $69 \%$ of the respondents pointed out that a persons with a disability are not a product. This result agrees with the results of studies (Abdat, 2014 [4]; Henry et al., 2014 [6]; Mansour, 2009 [26]; Hernandez et al., 2000 [42]; Woodely \& Metzgr, 2012 [47]; Kaye et al., 2011 [48]; McDonnell, 2014 [52]; Domzal et al., 2008 [53] Fuqua et al., 1984 [54]).

When looking at the results of the responses of the study participants to specifically items (1) and (3), the gap between law and reality is clear; there are (88.5\%) of the participants in the study pointed out that the right to employment for persons with disabilities, but (69\%) indicated that persons with disabilities are not producers. This means that persons with disabilities are not employed based on their qualifications, but according to pity and on humanitarian cases. There are (40.9\%) of the participants in the study indicated that the employment of persons with disabilities are out of pity or on humanitarian cases. In general, this result agrees with the results of studies (Bitar, 2013 [2]; Nyombi \& Kibandama, 2014 [8]; Nota et al., 2013 [19]; Vornholt et al., 2013 [21]; National Disability Authority \{NDA\}, 2005 [27]; Wilgosh \& Skaret, 1987 [46]) which indicated the existence of a gap between the law and reality. Also agree with what indicated by the results of studies (Abdat, 2014 [4]; Henry et al., 2014 [6]; Mansour, 2009 [26]; Barnes, 1992 [29]; Hernandez et L., 2000 [42]; Woodely \& Metzgr, 2012 [47]; Kaye et al., 2011 [48]; McDonnell, 2014 [52]; Domzal et al., 2008 [53]; Fuqua et al., 1984 [54]).

In the results of current study were concerns regarding the employment of persons with disabilities from the perspective the Jordanians people sorted by importance as shown in Table 3.

In general, the results of the current study, disagree with results studies Henry et al,, (2014 [6]) and Hernandez et al., (2008 [61]), which indicated to some employers who have employed people with disabilities found that employers perceive workers with disabilities as easy to supervise to have productivity levels equal to or higher than employees without disabilities and to have low absence rates. The differences in results of the present study with results of the previous studies may be due to the different methodologies, difference the target groups in each study, the difference in the places where the studies were conducted, a mandatory law in the country where the study was conducted and environmental facilities there.

To answer the second question "Are there any statistically significant differences between Jordanians people in the attitudes toward employment of persons with disabilities 
Table 3. Concerns regarding the employment of persons with disabilities from the perspective the Jordanians people sorted by importance $(\mathrm{n}=800)$.

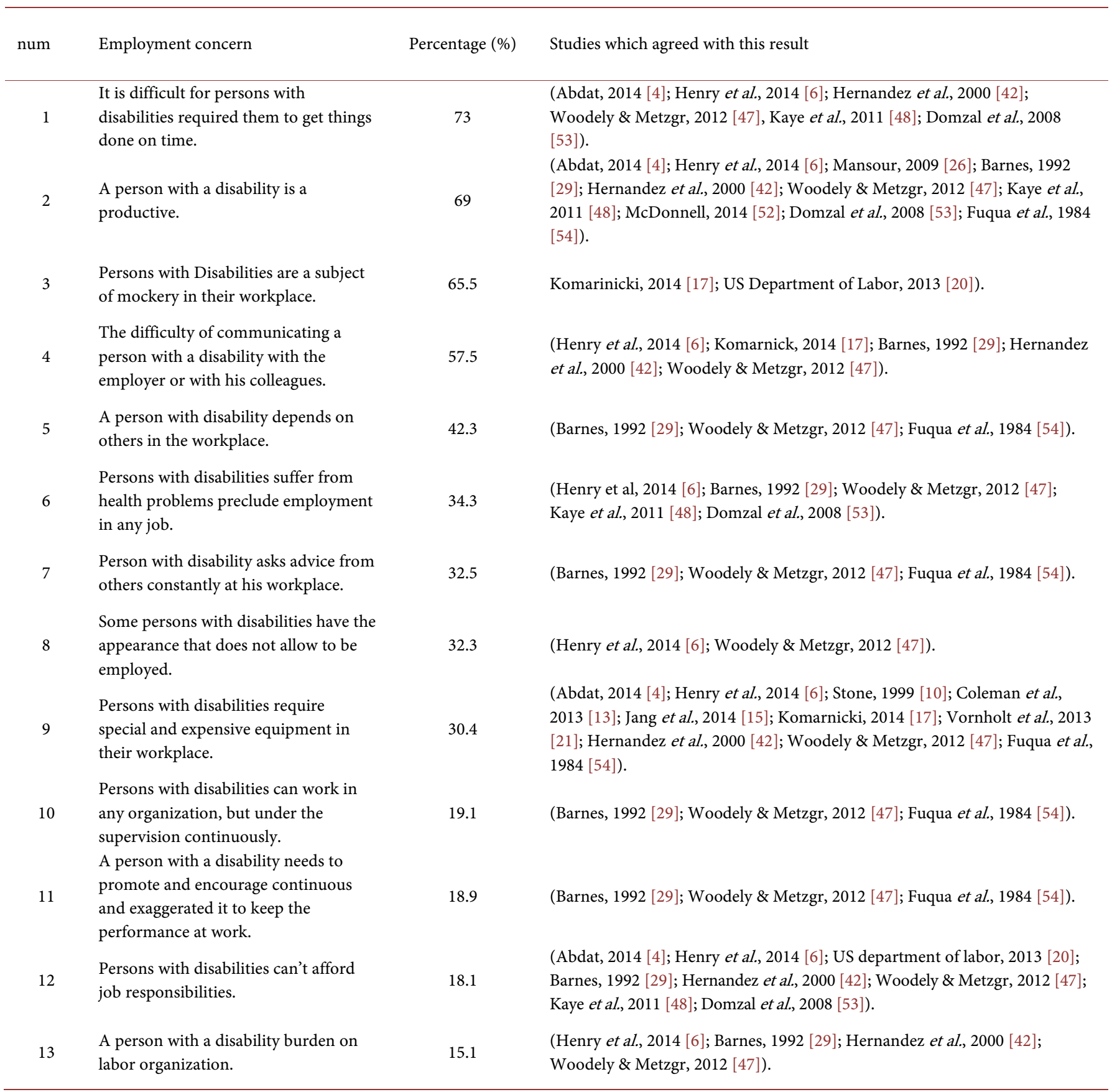

due to (gender, age, educational level, economic level and the existence of a disability in the individuals' family?). Means and Std. Deviations for the responses of study participants were computed. Table 4 shows that.

Table 4 shows that there are virtual differences between Jordanians people in attitudes toward employment of persons with disabilities. To know if these differences are statistically significant, 5 way ANOVA was applied. Table 5 shows that. 
Table 4. Means and Std. Deviations for the responses of study participants.

\begin{tabular}{|c|c|c|c|c|}
\hline Independent variable & $\begin{array}{l}\text { Level of independent } \\
\text { variable }\end{array}$ & Num & Mean & $\begin{array}{c}\text { Std. } \\
\text { Deviation }\end{array}$ \\
\hline \multirow{3}{*}{ Gender } & Male & 344 & 55.6 & 10.9 \\
\hline & Female & 450 & 56.7 & 10.2 \\
\hline & $\leq 35$ & 514 & 55.6 & 10 \\
\hline \multirow[t]{4}{*}{ Age } & 3650 & 226 & 57.9 & 11.6 \\
\hline & $\geq 51$ & 54 & 56.8 & 9.8 \\
\hline & Below secondary & 87 & 54 & 8.9 \\
\hline & Secondary & 182 & 55.9 & 9.9 \\
\hline \multirow[t]{3}{*}{ Educational level } & Diploma & 117 & 58.6 & 11.4 \\
\hline & Bachelor & 333 & 56 & 10.9 \\
\hline & high education & 75 & 57.1 & 10 \\
\hline \multirow[t]{3}{*}{ Economic level } & $\leq 300$ & 267 & 55.3 & 10 \\
\hline & $300-600$ & 392 & 57 & 10.9 \\
\hline & $\geq 600$ & 135 & 56.5 & 9.8 \\
\hline \multirow{2}{*}{ existence of a disability in the individual's family } & Existing & 93 & 52.9 & 9.8 \\
\hline & Does not exist & 701 & 56.8 & 10.6 \\
\hline
\end{tabular}

Table 5. Results of 5 way ANOVA.

\begin{tabular}{ccccc}
\hline Independent variable & df & Mean square & F & Sig \\
\hline Gender & 1 & 354.9 & 3.3 & 0.069 \\
Age (years) & 2 & 630.2 & 5.9 & $0.003^{*}$ \\
Educational level & 4 & 286 & 2.7 & $0.031^{*}$ \\
Economic level & 2 & 161.2 & 1.5 & 0.223 \\
$\begin{array}{c}\text { existence of a disability in the } \\
\text { individual's family }\end{array}$ & 1 & 948 & 8.8 & $0.003^{*}$ \\
Error & 783 & 107.208 & - & - \\
Total & 800 & - & - & - \\
\hline
\end{tabular}

${ }^{*}$ Statistically significant at the level of significance $(\mathrm{P} \leq 0.05)$.

Table 5 shows that there are no significant differences between Jordanian people in the attitudes toward employment of persons with disabilities due to gender. This result agrees with the result of Paez \& Arendt (2014 [37] ) which indicate that there were no statistically significant differences in the attitudes of employers' toward employment of persons with disabilities due to gender. Also Table 5, shows that there are significant differences between Jordanian people in the attitudes toward employment of persons with disabilities due to age, to know the in favor of the differences, the researcher conducted Scheffe' test and Table 6 shows that. 
Table 6. Result of Scheffe' test for variable age.

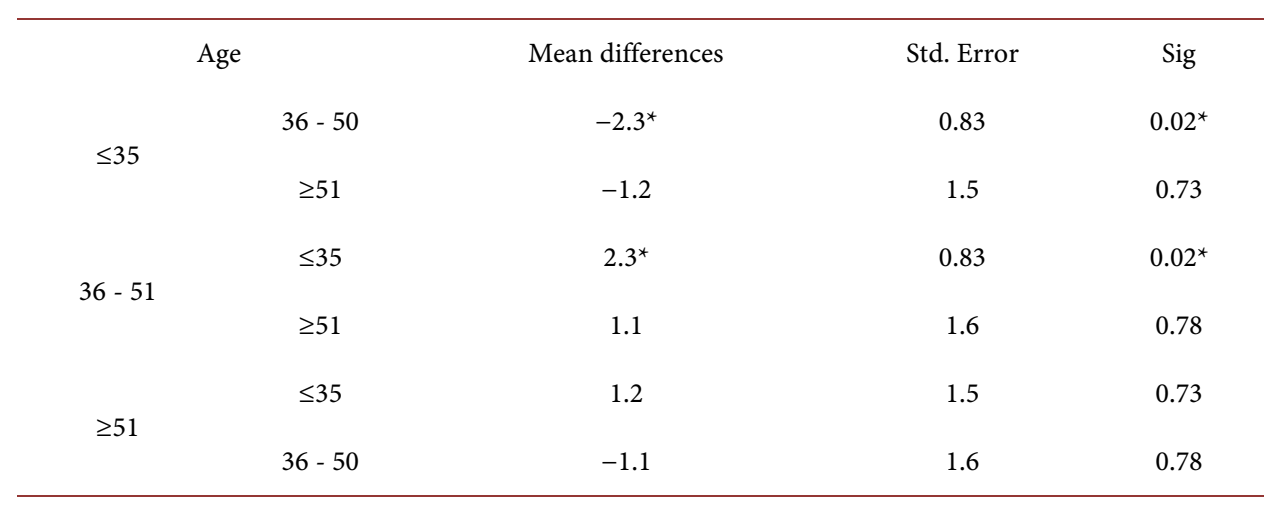

Table 6 shows that the differences in attitudes towards the employment of persons with disabilities due to age. Were in favor of the aged between (36 - 50) compared to people aged $\leq 35$. Result of this study disagree with the result of the study Paez \& Arendt (2014 [37]). These differences may be due to those who are younger than 35 looking for work so they see a person with a disability is a competitor in the opportunity to get a job. As well as differences in attitudes may be due to age (36-50) is most the average age of people who work, and who may have experience working with people with disabilities. As many studies have indicated that work experience with people with disabilities lead to positive attitudes toward employment of persons with disabilities (Henry et al., 2014 [6]; Gustafsson, et al., 2013 [14]; Nota et al., 2013 [19]; Vornholt et al., 2013 [21]; Wilgosh \& Skaret, 1987 [46]; Robert \& Melina, 2005 [49]; McDonnell, 2014 [52]; Unger, 2002 [57]; Hernandez et al., 2008 [61];). In any case, these conclusions need for further research. This result also disagrees with the result of Siperstein et al. (2014 [9]) study, which indicated that young employers attitudes towards the employment of persons with disabilities more positive compared to the elderly.

As well as when looking at the Table 5, there are significant differences between Jordanians people in attitudes towards the employment of persons with disabilities due to educational level. To know the in favor of the differences, the researcher conducted Scheffe' test and Table 7 shows that.

Table 7 shows that the differences in attitudes towards the employment of persons with disabilities due to educational level were in favor of the educational level diploma compared to people educational level below secondary. Also when looking to Table 5, evidenced there are no significant differences between Jordanians people in attitudes towards the employment of persons with disabilities due to economic level. This could be because most participants in the study have an income, not hurt them employing persons with disabilities. The last result in Table 5 is that there are no differences in attitudes towards the employment of persons with disabilities due to existence of a disability in the individual's family; the differences were in favor of the families who have a person with disability. This result agrees with the results of Heron \& Murray (2003 [35]) study. Which pointed out that one of barriers the employment of persons with disabilities is over protective by their families. 
Table 7. Result of scheffe' test for variable educational level.

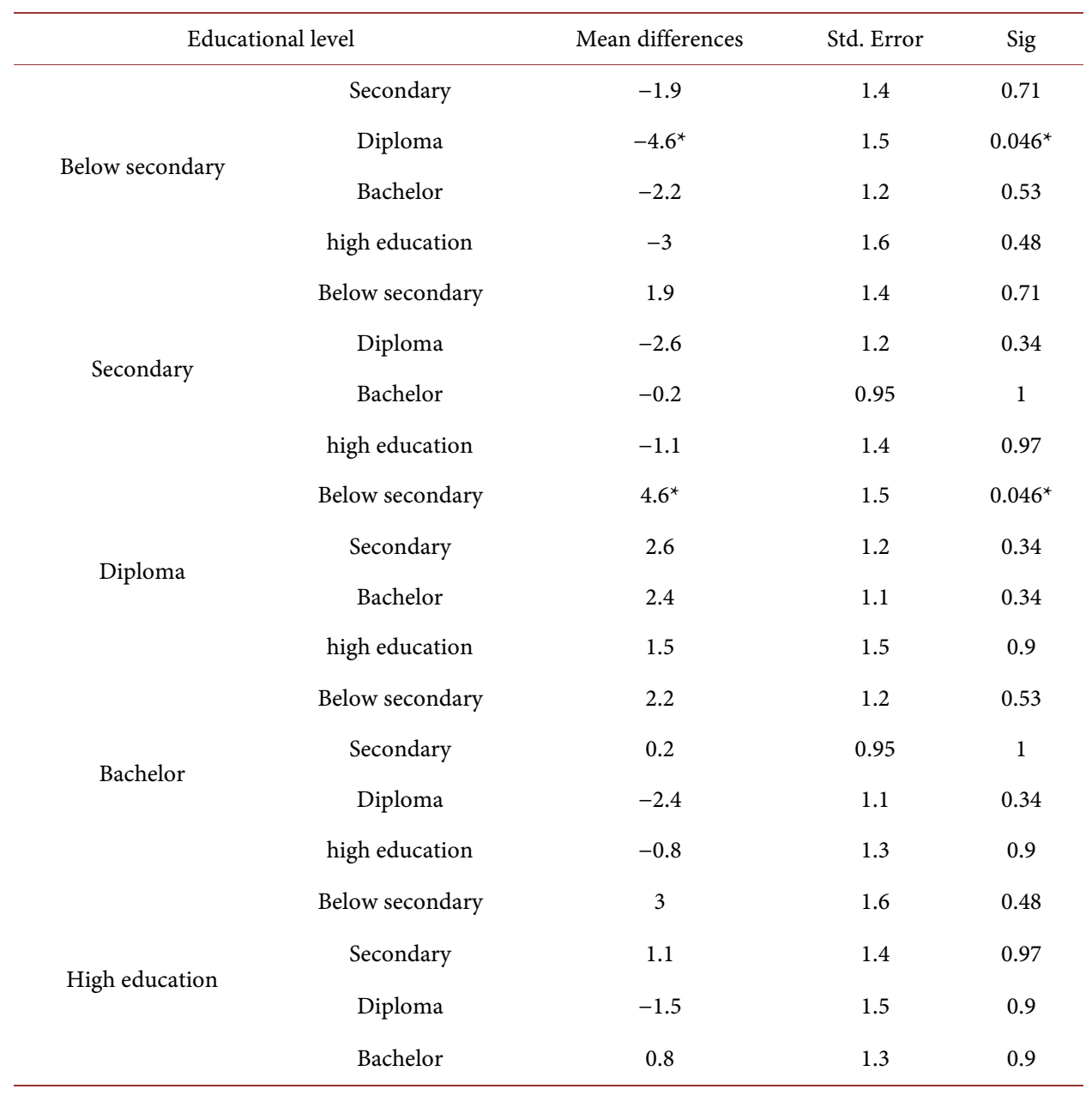

\section{Conclusions}

A sample of Jordanians people who may be employers, colleagues for persons with disabilities or clients target group in this study. Accordingly, the researcher recommends conducting studies on specific categories, also studying the effect of other variables on the attitudes towards the employment of persons with disabilities, such as a variable (work and having experience working with people with disabilities). Also conduct specialized studies to find out the reasons behind the lack of employment of persons with disabilities by employers.

In this study, the effect of economic level on the attitudes towards the employment of persons with disabilities was studied because of the researcher's belief that low-income. Those believe that a person with disability can contribute to raising the level of income when receiving the work. In any case, the researcher recommends the study of the effect of these variables, as well as the interaction between variables, economic level and the existence of a disability in the family.

In general, varying attitudes came in this study, where the majority of the participants in this study emphasized that the right of persons with disabilities to get a job. 
But the majority pointed to a number of concerns regarding the employment of persons with disabilities they noted the lack of productivity for people with disabilities, as well as frequent absences, and the inability to communicate effectively with employers or co-workers or clients and take responsibilities toward work. These concerns of the Jordanians people impede the employment of persons with disabilities. This requires an awareness of the rights of persons with disabilities to obtain employment as well as awareness of their ability to work by providing them with appropriate education and vocational rehabilitation program.

The vocational rehabilitation services providing persons with disabilities with vocational guidance, vocational training and Job referrals to help them to achieve vocational independence. Providing a person with disability vocational rehabilitation services is not enough. Rehabilitation will succeed when a person with a disability gets right to work; this requires forcing companies to activate the provisions of the law, and establishing private bodies to monitor the activation of provisions of the law by companies, Activate and improve transition services for persons with disabilities from school to work, establishing employing offices for the employment of persons with disabilities.

There are many strategies that help the employment of persons with disabilities, they are as follows: reduce of architectural barriers in public buildings and transportation, increase sheltered employment for some persons with disabilities, some persons with disabilities can work with people who have no disability in the open labor market and this requires providing support, the support persons with disabilities into integrated open employment should be encouraged by countries such as: incentive oriented quota system, cutting taxes on companies in exchange for the employment of a number of persons with disabilities, increase awareness of legal requirements, unless awareness of legal requirements is improved, persons with disabilities will continue to challenges to get a job, Granting Persons with Disabilities loans and bank facilities for the establishment their own businesses, an employment quota system that obliges employers to ensure that certain proportion of their employees are disabled, by the law on the rights of persons with disabilities (law number 31 for the year 2007), in public or private sectors organization with 100 or more employees, it is required that of least $4 \%$ of employees be disabled; and Impose sanctions on organization are not bound by the quota system the specified in the low. Organization failing to meet criteria must pay penalties.

Finally, work is right for persons with disabilities, and should not be practiced any discrimination towards them, such as giving those low wages, or underemployment, or depriving them of bonuses and incentives.

\section{References}

[1] Higher Council for Affairs of Personal with Disabilities \{HCD $\}$ (2007) International Convention on the Rights of Persons with Disabilities. http://hcd.gov.jo/node/946

[2] Bitar, L. (2013) The Right to Employment for People with Disabilities: A Study on Jordan. https://www.duo.uio.no/bitstream/handle/10852/35943/LenaBitar.pdf?sequence=1

[3] Higher Council for Affairs of Personal with Disabilities \{HCD $\}$ (2007) Law on the Rights of 
Persons with Disabilities. http://hcd.gov.jo/node/946.

[4] Abdat, R. (2014) Difficulties of Employment of Persons with Intellectual Disabilities in the United Arab Emirates (UAE). Meeting 14 for Gulf Society, Dubai, Emirates. http://www.gulfdisability.com/pdf/M14-Art-G2b.pdf

[5] Balcazar, F., Kuchak, J., Dimpfl, S., Sariepella, V. and Alvarado, F. (2014) An Empowerment Model of Entrepreneurship for People with Disabilities in the United States. Psychosocial Intervention, 23, 145-150. http://dx.doi.org/10.1016/j.psi.2014.07.002

[6] Henry, A., Petkauskos, K., Stanislawzyk, J. and Vogt, J. (2014) Employer-Recommended Strategies to Increase Opportunities for People with Disabilities. Journal of Vocational Rehabilitation, 41, 237-248.

[7] Jang, Y., Wang, Y., Lin, M. and Shih, K. (2013) Predictors of Employment Outcomes for People with Visual Impairment in Taiwan: The Contribution of Disability Employment Services. Journal of Visual Impairment \& Blindness, 469-480.

[8] Nyombi, C. and Kibandama, A. (2014) Access to Employment for Persons with Disabilities in Uganda. Labor Law Journal, 248-258.

[9] Sipersteien, G., Heyman, M. and Stokes, J. (2014) Pathways to Employment: A National Survey of Adults with Intellectual Disabilities. Journal of Vocational Rehabilitation, 41, 165-178.

[10] Stone, E. (Ed.) (1999) Disability and Development: Learning from Action and Research on Disability in the Majority World. The Disability Press, Leeds.

[11] Benshoff, L., Barrera, M. and Heyman, J. (2014) Disability Rights Advocacy and Employment: A Qualitative Study of the National Centre for the Employment of Disabled People (NCPEDP) in India. Work, 48, 453-464.

[12] Volker, M. (2014) Supported Employment in Argentina. Journal of Vocational Rehabilitation, 41, 77-81.

[13] Coleman, N., Sykes, W. and Groom, C. (2013) Barriers to Employment and Unfair Treatment at Work: A Quantitative Analysis of Disabled People's Experiences. Equality and Human Rights Commission Research, UK.

[14] Gustafsson, J., Peralta, J. and Danermark, B. (2013) The Employer's Perspective on Supported Employment for People with Disabilities: Successful Approaches of Supported Employment Organizations. Journal of Vocational Rehabilitation, 38, 99-111.

[15] Jang, Y., Wang, Y. and Lin, M. (2014) Factors Affecting Employment Outcomes for People with Disabilities Who Received Disability Employment Services in Taiwan. Journal of Occupational Rehabilitation, 24, 11-21. http://dx.doi.org/10.1007/s10926-013-9433-1

[16] International Labour Organization (2013) Emerging Good Practices Related to the Training and Job Placement of Persons with Disabilities in Lebanon.

http://www.ilo.org/wcmsp5/groups/public/---arabstates/---ro-beirut/documents/publicatio n/wcms_232973.pdf

[17] Komarnicki, C. (Ed.) (2014) Exploring Employment Opportunities for Persons with Disabilities. House of Commons, Canada.

[18] Nord, D., luecking, R., Mank, D., Kiernan, W. and Wary, C. (2013) The State of the Science of Employment and Economic Self-Sufficiency for People with Intellectual and Developmental Disabilities. Intellectual and Development Disabilities, 51, 376-384. http://dx.doi.org/10.1352/1934-9556-51.5.376

[19] Nota, L., Santilli, S., Ginevra, M. and Soresi, S. (2013) Employer Attitudes towards the Work Inclusion of People with Disability. Journal of Applied Research in Intellectual Disabilities, 27, 511-520. http://dx.doi.org/10.1111/jar.12081 
[20] US Department of Labor (2013) Persons with a Disability: Barriers to Employment, Type of Assistance, and other Labor-Related Issues-May 2012.

www.bls.gov/cps

[21] Vornholt, K., Uitdewilligen, S. and Nijhuis, F. (2013) Factors Affecting the Acceptance of People with Disabilities at Work: A Literature Review. Journal Occupation Rehabilitation, 23, 463-475. http://dx.doi.org/10.1007/s10926-013-9426-0

[22] Sing, D. (2012) Promoting the Employability and Employment of People with Disabilities in the South African Public Service. Public Personnel Management, 41, 161-171.

[23] Volker, M. (2012) Supported Employment and the Current Labor Situation for People with Disabilities in Argentina. Journal of Vocational Rehabilitation, 38, 207-214.

[24] Berthoud, R. (2011) Trends in the Employment of Disabled People in Britain. Institute for Social and Economic Research.

[25] Crawford, C. (2011) The Employment of People with Intellectual Disabilities in Canada: A Statistical Profile. Institute for Research and Development on Inclusion and Society, Canada.

[26] Mansour, M. (2009) Employers' Attitudes and Concerns about the Employment of Disabled People. International Review of Business Research Papers, 5, 209-218.

[27] National Disability Authority (NDA) (2005) Disability and Employment: What The Research Tells Us. NDA 4th Annual Disability Research Conference, Dublin, 11 October 2005. http://nda.ie/ndasitefiles/disability_research_conference2005.pdf

[28] Thornton, P. and Lunt, N. (1995) Employment for Disabled People: Social Obligation or Individual Responsibility? Social Policy Reports No 2.

[29] Barnes, C. (1992) Disability and Employment. http://disability-studies.leeds.ac.uk/files/library/Barnes-dis-and-emp.pdf

[30] Abu Melhim, M. (2015) The Policies of Employment of Persons with Disabilities in Jordan between Theory and Practice. Amwaj Publisher, Amman.

[31] Abu Sain, M. (2015) Data Persons with Disabilities Registered with Higher Council for the Affairs of Persons with Disabilities. Higher Council for the Affairs of Persons with Disabilities, Jordan.

[32] Higher Council for Affairs of Personal with Disabilities (HCD) (2010) The Reality of Disability in Jordan: Employment and Unemployment. http://dos.gov.jo/dos_home_a/main/Analasis_Reports/emp/Disability.pdf

[33] Azzeh, L. (2015) 7.7\% of People with Disabilities Are Employed-Report. The Jordan Times. http://static.jordantimes.com/news/local/77-people-disabilities-are-employed-\%E2\%80\%94 -report

[34] Ababneh, I. (2016) Disabled Employees in Jordanian Public Sector: An Exploratory Study. International Journal of Public Sector Management, 29, 164-182. http://dx.doi.org/10.1108/IJPSM-03-2015-0041

[35] Heron, R. and Murray, B. (2003) Assisting Disabled Persons in Finding Employment: A Practical Guide. International Labour Organization, Spain.

[36] Lysaght, R., Ouellette-Kuntz, H. and Jung Lin, C. (2012) Untapped Potential: Perspectives on the Employment of People with Intellectual Disability. Work, 41, 409-422.

[37] Paez, P. and Arent, S. (2014) Managers' Attitudes towards Employees with Disabilities in the Hospitality Industry. International Journal of Hospitality and Tourism Administration, 15, 172-190. http://dx.doi.org/10.1080/15256480.2014.901065

[38] Arikawa, M., Goto, H. and Mineno, K. (2013) Job Support by Occupational Therapists for 
People with Developmental Disabilities: Two Case Studies. Work, 45, 245-251.

[39] Employment Monitoring and Evaluation Branch (2011) Employer Perspectives on Recruiting People with Disability and the Role of Disability Employment Services. https://docs.employment.gov.au/system/files/doc/other/employer_perspectives_on_recruiti $\underline{\text { ng_people_with_disability_and_the_role_of_disability_employment_services.pdf }}$

[40] Siperstein, G., Romano, N., Mohler, A. and Parker, R. (2006) A National Survey of Consumer Attitudes towards Companies That Hire People with Disabilities. Journal of Vocational Rehabilitation, 24, 3-9.

[41] Florence, B. (2003) A Study of Employer Attitudes toward Hiring Individuals with Disabilities. The Able Trust, USA.

[42] Hernandez, B., Keys, C. and Balcazar, F. (2000) Employer Attitudes toward Workers with Disabilities and Their ADA Employment Rights: A Literature Review-Americans with Disabilities Act. Journal of Rehabilitation, 66, 4-16.

[43] Minskoff, S., Sautter, S., Hoffmann, F. and Hawks, R. (1987) Employer Attitudes toward Hiring the Learning Disabled. Journal of Learning Disabilities, 20, 53-57. http://dx.doi.org/10.1177/002221948702000108

[44] Boman, T., Kjellberg, A., Danermar, B. and Boman, E. (2013) Can People with Disabilities Gain from Education? Work, 49, 193-204.

[45] Heron, R. (2005) Job and Work Analysis Guidelines on Identifying Jobs for Persons with Disabilities. International Labor Office, Switzerland.

[46] Wilgosh, L. and Skaret, D. (1987) Employer Attitudes toward Hiring Individuals with Disabilities: A Review of the Recent Literature. Canadian Journal of Rehabilitation, 1, 89-98.

[47] Woodely, A. and Metzgrn, N. (2012) Employer Attitudes towards Employing Disabled People.

http://www.thinkdifferently.org.nz/sites/default/files/documents/Employers\%20Research.pdf

[48] Kaye, H., Jans, L. and Jones, E. (2011) Why Don't Employers Hire and Retain Workers with Disabilities? Journal of Occupational Rehabilitation, 21, 526-536. http://dx.doi.org/10.1007/s10926-011-9302-8

[49] Robert, M. and Melina, A. (2005) The Employer's Perception: Employment of Individuals with Developmental Disabilities. Journal of Vocational Rehabilitation, 23, 39-49.

[50] Berry, J. and Meyer, J. (1995) Employing People with Disabilities: Impact of Attitude and Situation. Rehabilitation Psychology, 40, 211-222. http://dx.doi.org/10.1037/0090-5550.40.3.211

[51] Kilbury, R., John, B. and Stanford, R. (1992) The Interaction of Legislation, Public Attitudes, and Access to Opportunities for Persons with Disabilities. The Journal of Rehabilitation, 58, 6-9.

[52] McDonnall, M. (2014) Employer Attitudes toward Blind or Visually Impaired Employees Initial Development of a Measurement Instrument. Rehabilitation Counseling Bulletin, 58, 29-36. http://dx.doi.org/10.1177/0034355213504140

[53] Domzal, C., Houtenville, A. and Sharma, R. (2008) Survey of Employer Perspectives on the Employment of People with Disabilities: Technical Report, Prepared under Contract to the Office of Disability and Employment Policy. US Department of Labor, CESSI, McLean.

[54] Fuqua, D., Rathbun, M. and Gade, M. (1984) A Comparison of Employer Attitudes toward the Worker Problems of Eight Types of Disabled Workers. Journal of Applied Rehabilitation Counseling, 15, 40-43.

[55] Stephen, D., Collins, M. and Dodder, R. (2005) A Longitudinal Study of Employment and 
Skill Acquisition among Individuals with Developmental Disabilities. Research in Developmental Disabilities, 26, 469-486. http://dx.doi.org/10.1016/j.ridd.2003.12.003

[56] Kulkarni, M. and Kote, J. (2013) Increasing Employment of People with Disabilities: The Role and Views of Disability Training and Placement Agencies. Employ Response Rights, 26, 177-193. http://dx.doi.org/10.1007/s10672-013-9216-Z

[57] Unger, D. (2002) Employers' Attitudes toward Persons with Disabilities in the Workforce Myths or Realities? Developmental Disabilities Research Reviews, 17, 2-10. http://dx.doi.org/10.1177/108835760201700101

[58] Gilbride, D., Stensrud, R., Ehlers, C., Evans, E. and Peterson, C. (2000) Employers' Attitudes toward Hiring Persons with Disabilities and Vocational Rehabilitation Services. The Journal of Rehabilitation, 66, 17-23.

[59] Smith, T. (1981) Employer Concerns in Hiring Mentally Retarded Persons. Rehabilitation Counseling Bulletin, 24, 316-318.

[60] Mithaug, D. (1979) Negative Employer Attitudes toward Hiring the Handicapped: Fact or Fiction? Journal of Contemporary Business, 8, 19-26.

[61] Hernandez, B., McDonald, K., Divilbiss, M., Horin, E., Velcoff, J. and Donoso, O. (2008) Reflections from Employers on the Disabled Workforce: Focus Groups with Healthcare, Hospitality and Retail Administrators. Employee Responsibilities and Rights Journal, 20, 157-164. http://dx.doi.org/10.1007/s10672-008-9063-5

[62] Visier, L. (1998) Sheltered Employment for Persons with Disabilities. International Labour Review, 137, 348-365.

\section{Submit or recommend next manuscript to SCIRP and we will provide best service} for you:

Accepting pre-submission inquiries through Email, Facebook, LinkedIn, Twitter, etc. A wide selection of journals (inclusive of 9 subjects, more than 200 journals)

Providing 24-hour high-quality service

User-friendly online submission system

Fair and swift peer-review system

Efficient typesetting and proofreading procedure

Display of the result of downloads and visits, as well as the number of cited articles

Maximum dissemination of your research work

Submit your manuscript at: http://papersubmission.scirp.org/

Orcontact jss@scirp.org 